\title{
Effect of different levels of Salinity on growth and photosynthetic pigments of Wheat Plants (Triticum aestivum L. Var. Raj- 3765).
}

\author{
Kiran mala ${ }^{1}$, T.I. Khan ${ }^{2}$ \\ ${ }^{I}$ (Indira Gandhi Centre for Human Ecology, Environmental and Population Studies, University of Rajasthan, \\ Jaipur-302004, India) \\ ${ }_{2}^{2}$ (Indira Gandhi Centre for Human Ecology, Environmental and Population Studies, University of Rajasthan, \\ Jaipur-302004, India)
}

\begin{abstract}
Plant growth is the result of many integrated and regulated physiological processes. Salinity, which is one of the major abiotic stresses, causes alterations in a wide range of physiological, biochemical and molecular processes in plants. It decreases plant growth and yield, depending on the plant species, salinity levels and ionic composition of the salts. In this study, Triticum aestivum L. var. Raj-3765 was selected as the test species. Six different levels of salinity were maintained to conduct the experiment for finding out level of tolerance of salinity by this crop plant. Salinity levels were prepared by adding different concentrations of Saline water $(S W)$ and double distilled water $(D W)$. The best growth of this crop plant was observed at level 2 i.e. $S W: D W: 10: 90$.
\end{abstract}

Keywords: Biomass, Chlorophyll (Photosynthetic pigment), Wheat and Salinity Stress.

\section{Introduction}

The two major natural environmental factors in the arid region that currently reduce plant productivity are drought and salinity. Salinity is a major environmental stress and is a substantial constraint to crop production [1]. High level of salts in the soil can often cause serious limitations to agricultural production and land development. The main factors that contribute to this problem are the arid and semi-arid climates and the salt load in the water used for irrigation [2]. There are a range of plants also that are capable of growing under conditions of saline soil and water [3]. [4] Reported that increasing salt concentration in the environment for germination, shoot and root length and dry weight can be reduced significantly. High level of salinity significantly reduced pigment content in leaves [5].

Wheat (Triticum aestivum L.) is a major cereal crop in many parts of the world and used as staple food. Wheat is a moderately salinity tolerant crop. It belongs to poaceae family. Therefore, increasing wheat production is a national target to fill the gap between production and consumption. The soil salinity may cause several deleterious effects on growth and development of plants at physiological and biochemical levels [6]. The electrical conductivity of the selected wheat cultivar was stimulated by salt stress. Tolerance to environmental stresses as salinity of plants can be determined by using different parameters. Salinity decreases root length, shoot length, root dry weight, shoot dry weight, total dry weight and chlorophyll content with increasing level of salinity. In the present study an experiment has been conducted in the laboratory of Indira Gandhi Centre for Human Ecology, Environmental and Population Studies, University of Rajasthan, Jaipur for studying salinity toleration by Wheat. Triticum aestivum L. var. Raj-3765 was selected as test species.

\section{Materials And Methods}

For the experimental study, wheat (Triticum aestivum L. var.Raj-3765) was selected as test species. Ten to fifteen identical seeds were sown in the beginning in each earthen pot (12" diameter earthen pots). The earthen pots were arranged to completely randomized design with three replication of each treatment. After the establishment of seedlings, a uniform population of five plants was maintained in each earthen pot.

Following six different levels of salinity were maintained by adding different amount of saline water (SW) and double distilled water (DW).

Level 1. SW: DW:: 00:100 (Control level)

Level 2. SW: DW:: 10:90

Level 3. SW: DW:: 25:75

Level 4. SW: DW:: 50:50

Level 5. SW: DW:: 75: 25

Level 6. SW: DW:: 100:00

The concentration of salinity varied from $1.4 \mathrm{mg} / \mathrm{L}$ (Control level) to $3890 \mathrm{mg} / \mathrm{L}$ (Level 6). The experiment was terminated when the plants completed post- flowering stage. The plants were harvested at the following three stages. 
1. Pre-flowering stage (after 78 days of treatment)

2. Peak-flowering stage (after 94 days of treatment)

3. Post-flowering stage (after 118 days of treatment)

Plants were harvested for growth analysis (like root length, shoot length, dry weight of root, shoot and total dry weight). Plant height was measured in centimeters. For dry weight determination, roots and shoots were separated and dried in hot air oven at $\quad 80^{\circ} \mathrm{C}$ for 72 hours. Chlorophyll (Photosynthetic pigment) concentration was estimated by methods suggested by [7].

Following formulae was employed to calculate the amount of chlorophyll a and $\mathrm{b}$.

Chlorophyll a mg/gm $=12.7 \times \mathrm{A}_{663}-2.69 \times \mathrm{A}_{645}$

Chlorophyll b mg/gm $=22.9 \times \mathrm{A}_{645}-4.68 \times \mathrm{A}_{663}$

Chlorophyll $(\mathrm{a}+\mathrm{b}) \mathrm{mg} / \mathrm{gm}=8.02 \times \mathrm{A}_{663}+20.20 \times \mathrm{A}_{645}$

\section{Results And Discussion}

The results of this study indicates that all the parameters i.e. length, dry weight and chlorophyll concentration were adversely affected with the increasing concentration of salinity, as given in Table 1 . Root length was $7.58 \mathrm{~cm}, 8.22 \mathrm{~cm}$ and $8.35 \mathrm{~cm}$ in the controlled condition at pre-flowering, peak-flowering and postflowering Stage respectively and slightly increased at salinity level 2 and it was observed to be $8.48 \mathrm{~cm}, 9.02 \mathrm{~cm}$ and $9.52 \mathrm{~cm}$. Then there was continuous decrease in root length. Shoot length was $23.68 \mathrm{~cm}, 25.06 \mathrm{~cm}$ and $26.18 \mathrm{~cm}$ in the controlled condition at pre-flowering, peak-flowering and post-flowering Stage respectively and slightly increased at salinity level 2 and it was observed to be $25.08 \mathrm{~cm}, 30.1 \mathrm{~cm}$ and $34.66 \mathrm{~cm}$. Then there was continuous decrease in shoot length.

Root dry weight was $0.0387 \mathrm{gm}, 0.0569 \mathrm{gm}$ and $0.0602 \mathrm{gm}$ in the controlled condition at preflowering, peak-flowering and post-flowering Stage respectively and slightly increased at salinity level 2 and it was observed to be $0.0534 \mathrm{gm}, 0.0706 \mathrm{gm}$ and $0.081 \mathrm{gm}$. Then there was continuous decrease in root dry weight. Shoot dry weight was $0.0769 \mathrm{gm}, 0.0885 \mathrm{gm}$ and $0.1843 \mathrm{gm}$ in the controlled condition at preflowering, peak-flowering and post-flowering Stage respectively and slightly increased at salinity level 2 and it was observed to be $0.1435 \mathrm{gm}, 0.1172 \mathrm{gm}$ and $0.2176 \mathrm{gm}$. Then there was continuous decrease in shoot dry weight. Total dry weight was $0.1156 \mathrm{gm}, 0.1455 \mathrm{gm}$ and $0.2445 \mathrm{gm}$ in the controlled condition at pre-flowering, peak-flowering and post-flowering Stage respectively and slightly increased at salinity level 2 and it was observed to be $0.1970 \mathrm{gm}, 0.1878 \mathrm{gm}$ and $0.2986 \mathrm{gm}$. Then there was continuous decrease in total dry weight. Chlorophyll a was $2.0701 \mathrm{mg} / \mathrm{gm}, 2.9605 \mathrm{mg} / \mathrm{gm}$ and $2.7296 \mathrm{mg} / \mathrm{gm}$ in the controlled condition at preflowering, peak-flowering and post-flowering Stage respectively and slightly increased at salinity level 2 and it was observed to be $3.0420 \mathrm{mg} / \mathrm{gm}, 4.3333 \mathrm{mg} / \mathrm{gm}$ and $4.2146 \mathrm{mg} / \mathrm{gm}$.

Table 1: Effect of different levels of salinity on growth and biochemical parameters of Wheat (Triticum aestivum L. var. Raj-3765).

\begin{tabular}{|c|c|c|c|c|c|c|c|c|c|c|c|c|c|c|c|c|c|c|}
\hline \multirow[t]{4}{*}{ Panaters } & \multicolumn{6}{|c|}{ Preflomering } & \multicolumn{6}{|c|}{ Peak-fluncring } & \multicolumn{6}{|c|}{ Past-flutering } \\
\hline & DNES & $D \pi 5$ & DWES & DNES & DWI:S & DW. 5 & DIT:S & DIFS & DII:S & DWIS & DW:S & DN.S & DWI:S & DWIS & DIT:S & DW:S & DWI:S & DW:S \\
\hline & & $\pi$ & $\pi$ & $\pi$ & $\pi$ & $\pi$ & $\pi$ & $\pi$ & $\pi$ & $W$ & $\pi$ & $\pi$ & $\pi$ & $\pi$ & $\pi$ & $\pi$ & $\pi$ & $\pi$ \\
\hline & $100: 00$ & $9: 10$ & $7: 25$ & $50: 50$ & $25: 75$ & ate 103 & 100:00 & 9t:10 & $75: 15$ & $50: 50$ & $25: 5$ & $90: 10)$ & $10: 00$ & $90: 10$ & $3: 25$ & $50: 50$ & $25: 75$ & 00:109 \\
\hline Rot leaghth & $758=$ & $84 \pm$ & $804=$ & $786=$ & $7.42=$ & $6.8=$ & $822=$ & $9.02 \pm$ & $8.64=$ & $83 i=$ & $8.14 \pm$ & $7.26=$ & $835=$ & $9.52=$ & $9.14=$ & $846=$ & $814=$ & $756 \pm$ \\
\hline (al) & 1.132 & 0.476 & Q.512 & 0.654 & 0.576 & 0.656 & 0.192 & 0.653 & 0.634 & 0.668 & 0.279 & 0.502 & 0.726 & 0.554 & 0.610 & 0.605 & 0.270 & 0.753 \\
\hline Shoot length & $23.68=$ & $5001 \pm$ & $2408=$ & $2306=$ & $2268=$ & $21.64=$ & $2506 \pm$ & 30.1 $1=$ & $29.44=$ & $29.06=$ & $2402=$ & $23.54 \pm$ & $2618=$ & $3+66=$ & $3102=$ & $29.84=$ & $5.14=$ & $24.22=$ \\
\hline (a) & 4.045 & 2716 & 3.87 & 2864 & 3.381 & 2.905 & 3.810 & 1.246 & 1.031 & 1.24 & 2725 & 1.93 & 3.54 & 2.89 & 4.053 & 1.114 & 1.192 & 1.334 \\
\hline Rostdry & 0.0387 & 0.6334 & 0.0466 & D.MLA & $0.03+9$ & 0.075 & 0.0560 & 0.0786 & $0.064 \pm$ & 0.6592 & 0.0486 & 0.0344 & 0.0602 & $0 .(8)=$ & $0.072=$ & 0.0694 & 0.0524 & 0.0433 \\
\hline reight (gm) & $=0.012$ & $=0.014$ & $=0.013$ & $=0.006$ & $=0.03$ & $=0.613$ & $=1.011$ & $=0.010$ & 0.013 & $=0.013$ & $=0.007$ & $=0.012$ & $=0.024$ & 0.011 & 0.011 & $\Rightarrow 0.008$ & $=1.019$ & $\Rightarrow 0.014$ \\
\hline Shost dry & 0.0769 & 0.1435 & 0.1077 & 0.013 & 0.0602 & 0.602 & 2.0385 & 0.1172 & 0.1118 & 0.1052 & 0.0324 & 0.0748 & 0.1843 & 0.2176 & 0.2991 & 0.2016 & 0.1505 & 0.1398 \\
\hline weight (gin & $=0.027$ & $=0.027$ & $=0.04\}$ & $=0,009$ & $\Rightarrow 0.05$ & $=0.007$ & $=0.022$ & $=0.010$ & $=0.011$ & $\Rightarrow 0.10$ & $=1.018$ & $\Rightarrow 0.010$ & $=1.051$ & $=0.068$ & $=0.037$ & $=0.036$ & $=1.010$ & $=0.001$ \\
\hline Totaldry & 0.1156 & 0.1970 & 0.1563 & 0.1567 & 0.0.051 & 0.0778 & 0.1453 & 0.1878 & 0.1748 & 0.1654 & 0.1310 & 0.1092 & 0.245 & 0.2066 & 0.2812 & 0.2710 & 0.839 & 0.1831 \\
\hline weight (gmi) & $=1.036$ & $=0.021$ & $=0.038$ & $=0.015$ & $=0.000$ & $=0.012$ & $=1.031$ & $=0.015$ & $=1.02$ & $=0.021$ & $=0.019$ & $=0.016$ & $=1.054$ & $=0.064$ & $=0.036$ & $=0.051$ & $=0.022$ & $=0.028$ \\
\hline Cblorophtyll & 2.0001 & 3.0420 & 2.8573 & 23635 & 1.9331 & 1.8723 & 29665 & 4.3333 & 4.240 & 3.5082 & 29058 & 2.7655 & 27296 & 4.2146 & 3.7705 & 3.1172 & 24333 & 2.1852 \\
\hline a (ingegn) & $=0.673$ & $=0.378$ & $=0.580$ & $=0.412$ & $=0.49$ & $=0.393$ & $=0.363$ & $=0.550$ & $=0.597$ & $=0.363$ & $=1.293$ & $=0.334$ & $=0.380$ & $=0.42 .4$ & $=0.636$ & $=0.459$ & $=0.45$ & $=0.280$ \\
\hline Chloopoptrill & 1.445 & 26007 & 1.8653 & 1.6835 & 1.478 & 1.3344 & 2.1865 & 3.0014 & 3.1826 & 2.8191 & 20314 & 1.7315 & 2.2763 & 3.0739 & 27381 & 2.3216 & 17183 & 1.8871 \\
\hline b(ing grin) & $=0.214$ & $=0.415$ & $=0.221$ & $=0.332$ & $=0.162$ & $=0.206$ & $=0.417$ & $=0.522$ & $=0.154$ & $=0.403$ & $=1.397$ & $\Rightarrow 0.228$ & $=2.570$ & $=0.482$ & $=0.554$ & $=0.522$ & $=0.125$ & $\Rightarrow 0.342$ \\
\hline & 3.5283 & 5.0919 & 4.7213 & 4.459 & 3.4166 & 320058 & 5.1456 & 8.1323 & 7.4213 & 6.4135 & 4.9358 & 4.4998 & 4.6669 & 7.885 & 65168 & 5.4372 & 4.2886 & 3,7713 \\
\hline $\begin{array}{l}\text { cllorophrll } \\
\text { (nggeni) }\end{array}$ & $=0.433$ & $=0.540$ & $=0.699$ & $=0.510$ & $=1.579$ & $=0.526$ & $=1.574$ & $=0.325$ & $=1.23 t$ & $\Rightarrow 0.553$ & $=0.583$ & $=0.486$ & $=0.571$ & $=0.494$ & $=0.302$ & $=0.596$ & $=1.52$ & $=0.212$ \\
\hline
\end{tabular}


Table 2: Mean sum of squares due to effect of different levels of salinity on different parameters of wheat (Triticum aestivum L. var. Raj-3765).

\begin{tabular}{|c|c|c|c|c|c|c|c|c|c|}
\hline Source & DF & Root Length & $\begin{array}{l}\text { Shoot } \\
\text { Length }\end{array}$ & $\begin{array}{ll}\text { Root Dry } \\
\text { Weight }\end{array}$ & $\begin{array}{ll}\text { Shoot } & \text { Dry } \\
\text { Weight } & \end{array}$ & $\begin{array}{l}\text { Total Dry } \\
\text { Weight }\end{array}$ & $\begin{array}{l}\text { Chlorophyll } \\
\text { a }\end{array}$ & $\begin{array}{l}\text { Chlorophyll } \\
\text { b }\end{array}$ & $\begin{array}{l}\text { Chlorophyll } \\
(\mathbf{a}+\mathbf{b})\end{array}$ \\
\hline Stage & 2 & $\begin{array}{l}5.640 \\
\left(3.61 \mathrm{E}-06^{* *}\right)\end{array}$ & $\begin{array}{l}194.061 \\
\left(4.67 \mathrm{E}-09^{* *}\right)\end{array}$ & $\begin{array}{l}0.0036 \\
(4.47 \mathrm{E}-07 * *)\end{array}$ & $\begin{array}{l}0.084 \\
(3.30 \mathrm{E}-22 * *)\end{array}$ & $\begin{array}{l}0.116 \\
(1.96 \mathrm{E}-22 * *)\end{array}$ & $\begin{array}{l}9.559 \\
\left(4.21 \mathrm{E}-13^{* *}\right)\end{array}$ & $\begin{array}{l}7.161 \\
\left(9.14 \mathrm{E}-11^{* *}\right)\end{array}$ & $\begin{array}{l}33.501 \\
(3.85 \mathrm{E}-20 * *)\end{array}$ \\
\hline $\begin{array}{l}\text { Int.Stg } \\
x \\
\text { Level }\end{array}$ & 10 & $\begin{array}{l}0.068 \\
\left(9.97 \mathrm{E}-01^{\mathrm{ns}}\right)\end{array}$ & $\begin{array}{l}12.453 \\
\left(1.17 \mathrm{E}-01^{\mathrm{ns}}\right)\end{array}$ & $\begin{array}{l}0.0000 \\
\left(9.97 \mathrm{E}-01^{\mathrm{ns}}\right)\end{array}$ & $\begin{array}{l}0.001 \\
\left(5.96 \mathrm{E}-01^{\mathrm{ns}}\right)\end{array}$ & $\begin{array}{l}0.001 \\
\left(8.12 \mathrm{E}-01^{\mathrm{ns}}\right)\end{array}$ & $\begin{array}{l}0.138 \\
\left(7.85 \mathrm{E}-01^{\mathrm{ns}}\right)\end{array}$ & $\begin{array}{l}0.372 \\
\left(1.01 \mathrm{E}-01^{\mathrm{ns}}\right)\end{array}$ & $\begin{array}{l}0.758 \\
(4.50 \mathrm{E}-02 * *)\end{array}$ \\
\hline Error & 72 & 0.376 & 7.659 & 0.0002 & 0.001 & 0.001 & 0.220 & 0.221 & 0.378 \\
\hline
\end{tabular}

Data in parenthesis indicate $\mathrm{P}$ values.

**Significant at $1 \%$.

ns (Non-Significant)

Then there was continuous decrease in chlorophyll a. Chlorophyll b was $1.5485 \mathrm{mg} / \mathrm{gm}, 2.1865 \mathrm{mg} / \mathrm{gm}$ and $2.2063 \mathrm{mg} / \mathrm{gm}$ in the controlled condition at pre-flowering, peak-flowering and post-flowering Stage respectively and slightly increased at salinity level 2 and it was observed to be $2.0507 \mathrm{mg} / \mathrm{gm}, 3.8014 \mathrm{mg} / \mathrm{gm}$ and $3.0739 \mathrm{mg} / \mathrm{gm}$. Then there was continuous decrease in chlorophyll b. Total Chlorophyll (a+b) was 3.5283 $\mathrm{mg} / \mathrm{gm}, 5.1456 \mathrm{mg} / \mathrm{gm}$ and $4.6669 \mathrm{mg} / \mathrm{gm}$ in the controlled condition at pre-flowering, peak-flowering and postflowering Stage respectively and slightly increased at salinity level 2 and it was observed to be $5.0919 \mathrm{mg} / \mathrm{gm}$, $8.1323 \mathrm{mg} / \mathrm{gm}$ and $7.2865 \mathrm{mg} / \mathrm{gm}$. Then there was continuous decrease in total chlorophyll $(\mathrm{a}+\mathrm{b})$.

In the present study, salinity caused a great reduction in growth parameters (root length, shoot length and dry weight of root and shoot) and chlorophyll content of Wheat with the increase in salinity levels. The term salinity includes all the problems due to presence of salts in the soil and it interferes in the growth of most crop plants [8]. Salinity is a major factor in reducing the growth and the productivity of plants [9]. Reduction in plant growth as a result of salt stress had also been reported in several other plant species [10]. Concentration of Nacl had a negative effect on agronomic parameters and limited the growth of plants and salt injury symptoms e.g. chlorosis were clearly visible in the plants at high Nacl concentration [11], [12] and [13]. [14] and [15] reported that salinity could seriously change the photosynthetic carbon metabolize, leaf chlorophyll content as well photosynthetic efficiency.

The analysis of variance (ANOVA) revealed that with the increase in salinity levels, there was decrease in all the parameters of Triticum aestivum L. var.Raj-3765. Mean sum of square (MSS) values and P values are given in the Table 2. The results are highly significant for harvesting stages and the different salinity levels maintained in the experiment. The results are non-significant for interactions among the harvesting stages and the salinity level maintained in all the growth parameters and highly significant for total chlorophyll.

\section{Conclusion}

The assessment of the effect of salinity on biomass and chlorophyll concentration in wheat plant (Triticum aestivum L.) Var. Raj- 3765 leads to the conclusion that all the considered parameters were significantly affected by salt stress. Results of the experiment revealed that the growth was best at level 2 i.e. SW: DW:: 10:90. Beyond this level of salinity there was more of adverse effect on all the parameters studied. Production of salt tolerant plants is one of the ways to utilize the waste saline water and lands. The results of this study will be helpful and suggests as what measures can be taken against this menace in our study area.

\section{Acknowledgements}

The authors are grateful to the Dean, Faculty of Science, University of Rajasthan and Director, Indira Gandhi Centre for Human Ecology, Environment and Population Studies, University of Rajasthan for providing necessary facilities and to UGC for the award of Rajiv Gandhi National Research Fellowship to one of the authors.

\section{References}

[1]. A.A. Radi, F.A. Farghaly, and A.M. Hamada, Physiological and biochemical responses of salt-tolerant and salt-sensitive wheat and bean cultivars to salinity, Journal of Biology and Earth Sciences, 3 (1), 2013, B72-B88.

[2]. R. Kumar, M.P. Singh, and S. Kumar, Effect of salinity on germination, growth, yield and yield attributes of wheat, International Journal of Scientific \& Technology Researc, 1 (6), 2012, 19-23.

[3]. M.M. Hussein, L.K. Balbaa, and M.S. Gaballah, Developing a salt tolerant cowpea using Alpha Tocopherol, Journal of Applied Sciences Research, 3(10), 2007, 1234-1239. 
[4]. H. T. Rahimi, E. H. Majidi, and M. Shahbazi, Evaluation of physiological and morphological indices on tolerance to salinity stress in forage sorghum: Abstracts proceeding of the 5th Iranian crop production and breeding congress, Seed and plant improvement Institute, Karaj, Iran, 1998

[5]. O.A. Al-Sobhi, H.S. Al-Zaharani, and S.B. Al-Ahmadi, Effect of salinity on chlorophyll and carbohydrate contents of Calotropis procera seedlings, Scientific Journal of King Faisal University (Basic and Applied Sciences),7, 2006, 11427H.

[6]. R.C. Munns, Comparative physiology of salt and water stress, Plant Cell Environ, 25, 2002, 239-250.

[7]. D.T. Arnon, Copper enzymes in isolated Chloroplast polyphenol oxidase in Beta vulgaris, Plant Physiol, 24, 1949, 1-15.

[8]. K. Mala, and T.I. Khan, Study of salinity in selected areas of sambhar town, GJBB, 3(3), 2014, 334-335.

[9]. A.A. Ehsapour, and N. Fatahian, Effect of salt and proline on Medicago sativa callus, Plant Cell Tissu and Organ Culture, 73, 2003, 73- 56.

[10]. M. Ashraf, J.M. O’leary, Ion distribution in leaves of salt-tolerant and salt-sensitive lines of spring wheat under salt stress, Acta Bot. Neerl, 46(2), 1997, 207-217.

[11]. V.D. Taffouo, J.K. Kouamou, L.M.T. Ngalangue, B.A.N. Ndjeudji, and A. Akoa, Effects of Salinity Stress on Growth, Ions Partitioning and Yield of Some Cowpea (Viigna unguiculata L. Walp.) Cultivars, International Journal of Botany, 5 (2), 2009, 135143.

[12]. S.S. Kachout, A.B. Mansoura, K. Jaffel, J.C. Leclerc, M.N. Rejeb, and Z. Ouerghi, The effect of salinity on the growth of the halophyte atriplex hortensis (chenopodiaceae), Applied ecology and environmental research, 7(4), 2009, 319-332.

[13]. M.R. Amirjan, Effect of NaCL on some physiological parameters of rice, EJBS, 3(1), 2010, 06-16.

[14]. J.R. Seeman, and C. Critchley, Effects of salt stress on the growth, ion content, stomatal behavior and photosynthetic capacity of salt-sensitive species Phaseolus Vulgaris (L), Planta, 164, 1985, 152-162.

[15]. T.D. Sharkey, J.R. Seeman, and J.A. Berry, Photosynthesis in intact leaves of C3 plants: physics, physiology and rate limitations, Bot. Rev, 51, 1989, 53-105. 